\title{
The impact of macroalgal blooms on the use of the intertidal area and feeding behaviour of waders (Charadrii) in the Mondego estuary (west Portugal)
}

\author{
João Alexandre Cabral *, Miguel Â. Pardal, Ricardo J. Lopes, Tiago Múrias, João Carlos Marques \\ Departamento de Zoologia, IMAR - Institute of Marine Research Coimbra, Universidade de Coimbra, 3000 Coimbra, Portugal. \\ * Corresponding author (fax: +351 39 23603; e-mail: imar@cygnus.ci.uc.pt)
}

Received February 26, 1998; revised December 30, 1998; accepted February 26, 1999

\begin{abstract}
The present paper examined the possible impact of macroalgal blooms, among other influential factors, on prey abundance and availability to waders, assessing the consequences for feeding behaviour and for the specific patterns of use of the intertidal areas by these birds when macroalgal mats become dense and contiguous covering large areas of the Mondego estuary (west Portugal). Three representative microhabitats were chosen in intertidal flats to control and evaluate the effects of various factors on waders. This study shows that foraging waders did not seem to be indifferent to the effects of some biological factors, sediment characteristics and epistructures when selecting feeding microhabitats. Overall, the results suggest that the predominant and constant negative effects on specific patterns of use of the intertidal sub-areas by the majority of waders were determined by two main factors: gull perturbation and macroalgal biomass. The macroalgal blooms assumed, by their persistence over a period of several months, a different magnitude of effect when compared with sporadic factors such as gull presence. Contrary to the effects on distribution, macroalgal blooms do not influence negatively the feeding behaviour parameters considered. Moreover, we were unable to prove that the presence of macroalgae on the sediment was pernicious to the wader prey organisms, perhaps because the total amount of the area of the estuary affected by weed during the study period never exceeded $36 \%$ and was surrounded by important algal-free areas that ensured a healthy prey population. Nevertheless, on the long-term, an increase of dense and contiguous macroalgal mats due to the progressive eutrophication of the Mondego estuary, covering large areas of the intertidal flats, may affect directly or indirectly all wader species. (c) 1999 Éditions scientifiques et médicales Elsevier SAS
\end{abstract}

Shorebirds / waders (Charadrii) / eutrophication / foraging behaviour / zoobenthos

\section{INTRODUCTION}

Most European estuaries are affected by organic pollution, which often gives rise to eutrophication [6, 16, 52]. Eutrophication as a response to nutrient enrichment, may commonly cause proliferation of opportunistic green macroalgae, such as Enteromorpha spp. and Ulva spp., which can cover extensive areas of the estuarine intertidal zone [21, 22]. The increase in macroalgal biomass, and possible shift of other primary producers resulting from eutrophication, may have profound effects on underlying invertebrate assemblages through deoxygenation of the sediment $[2,5,9,15,17,28,29,41,44,48]$.

In the Mondego estuary, blooms of green macroalgae, primarily Enteromorpha spp., have been observed from early spring to late summer [23, 24, 25, 34], which is a clear sign of nutrient enrichment. Each year, following the blooms, the decline of algal populations contributes significant quantities of dead organic material to the sediments. This causes, at least in some places, anoxic conditions in the underlying sediments. As a result of competition with algae, the extension of the seagrass meadows (mainly Zostera noltii) has been reduced, which may cause a shift in primary producers. Through time, this process may give origin to a new trophic structure. The energy flow at the secondary and tertiary levels will be affected, which may finally affect the populations from the upper trophic level organisms in this case dominated by waders [14, $26,41]$.

In a broad-scale overview of the Mondego estuary, Múrias et al. [32] suggested that the presence of algae over the sediments did not strongly influence the distribution of the feeding waders or, alternatively, that 
most waders were able to adapt to feeding on weedcovered areas. A fine-scale perspective, in plots where the information related to prey abundance, macroalgal biomass and bird densities are well controlled, is indispensable to corroborate this overview.

The aims of the present paper were to test if macroalgal growth influences, among other influential factors and by its potential effect on prey abundance and availability, the feeding behaviour and specific patterns of use of the intertidal areas by waders when macroalgal mats become dense and contiguous, covering large areas of the estuary.

\section{MATERIALS AND METHODS}

\subsection{Study area}

The Mondego estuary is warm-temperate in a region with a basic Mediterranean climate. The terminal part of the estuary consists of two arms, north and south, that surround the Murraceira island (figure la). The two arms of the estuary are hydrologically very different. The north arm is deeper, and most of the freshwater discharge from the river flows through it. The south arm is almost silted up in the upstream areas and the water circulation in this arm is almost entirely due to tides and to the freshwater input of a tributary, the Pranto river (figure 1a). Intertidal mud flats are much more extensive in the south arm, and therefore provide the most suitable areas for feeding by waders. The present study was therefore focused on the south arm mud flats.

\subsection{Wader census}

The counts were carried out from October 1993 to May 1994, including the two main periods for wader abundance in the Mondego estuary, the wintering and spring migration periods. For the purpose of this study, three sub-areas (1, 2 and 3 ) were chosen for counts (figure $1 b$ ), since this procedure is considered the best way to control and evaluate the effects of factors on the specific patterns of use of the intertidal area by waders [35]. These sub-areas, all of 1 ha, represented the principal feeding microhabitats that characterised the south arm. Considering the muddy substrates covered by vegetation, sub-areas 1 and 2 corresponded respectively to dense and sparse eelgrass (Zostera noltii) meadows. Sub-area 3 corresponded to muddysand substrates without $Z$. noltii meadows [23, 24]. During the study period, we carried out ten monthly counts in each sub-area, five on spring tides and five on neap tides. Every sequence of five counts was made from $2 \mathrm{~h}$ before to $2 \mathrm{~h}$ after the time of low-water peak (one count per h). Bird densities (birds $\cdot \mathrm{ha}^{-1}$ ) were

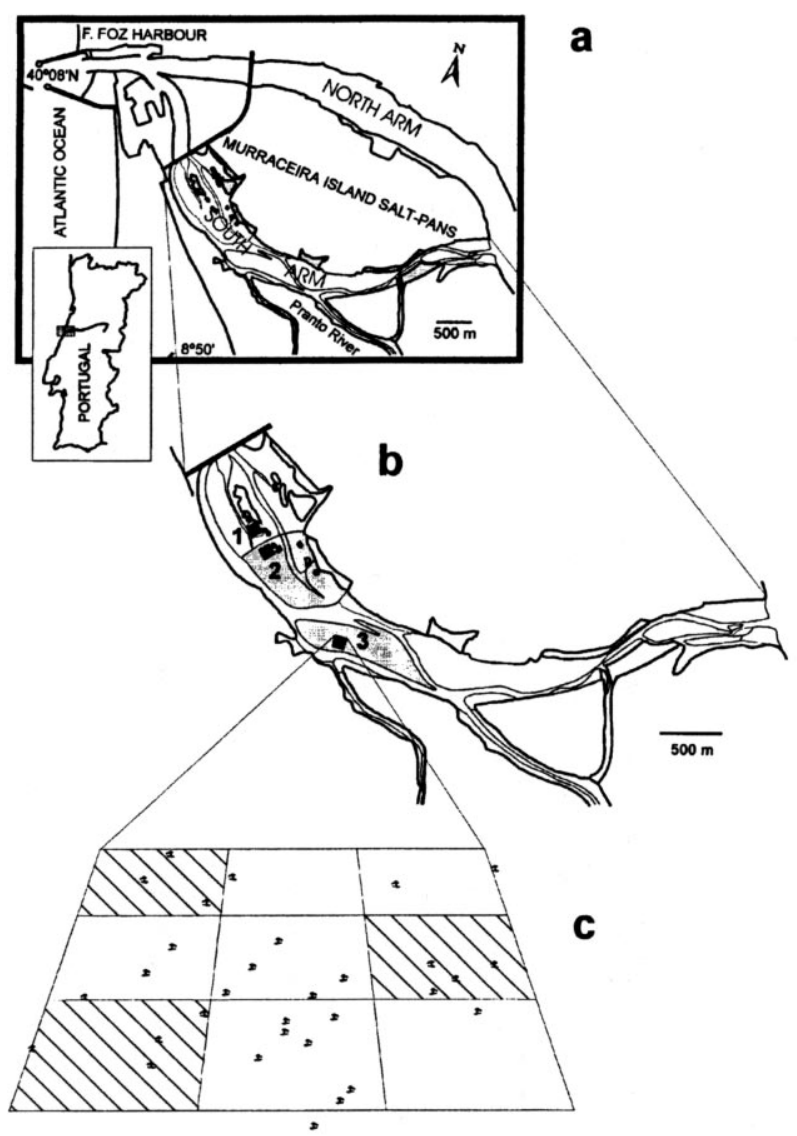

Figure 1. (a) Mondego estuary. (b) The south arm of the estuary where three sub-areas (1,2 and 3) were chosen for sampling counts, representing the principal feeding microhabitats (in grey). (c) Detail of a sub-area with quadrangular references.

recorded for each count in each sub-area (figure 1c). The mean specific densities (D) estimated from each sequence of five counts allowed us to determine the mean proportion $(\mathrm{P})$ of feeding waders that occurred in each sub-area. For example the proportion of feeding waders represented in sub-area 1 , in a given period $t$, was calculated by:

$$
\mathrm{P} 1 t=\mathrm{D} 1 t /(\mathrm{D} 1 t+\mathrm{D} 2 t+\mathrm{D} 3 t)
$$

where 1,2 and 3 are, respectively, sub-areas 1,2 and 3.

$\mathrm{P}$ was considered an indicator of sub-area preference by waders, integrating the natural and seasonal fluctuations in abundance over the study period.

Four wader species were considered in detail because of their importance in number and permanency: family Charadriidae - Kentish plover (Charadrius 
alexandrinus), ringed plover (Charadrius hiaticula) and grey plover (Pluvialis squatarola), family Scolopacidae - dunlin (Calidris alpina) [33].

\subsection{Behavioural observations}

The behavioural study is concerned with plovers (Charadriidae), which forage by a visual technique apparently without the element of tactile searching normally used by the Scolopacidae $[3,7,14,30,36$, 37, 40], for three reasons. First, plovers feed in the highly characteristic and stereotyped 'stop-run-peck' manner [3, 30, 37], which permits a reliable record of feeding behaviour. Second, plovers have a high feeding success with peck rates close to the real foodintake rates $[4,36,47,54]$, which is a direct function of the density of harvestable prey [38]. Third, plovers forage almost entirely visually, detecting and catching prey by exploiting their periods of surface activity, reflecting surface food detectability [36, 37].

The field work was carried out during the same period as the bird census (above). Observations of feeding behaviour were made between the counts of birds on the three sub-areas chosen in the south arm (figure $1 b$ ).

The duration of each observation was between $30 \mathrm{~s}$ and $1 \mathrm{~min}[36,37]$ and was recorded on tape. An observation was terminated if the bird stopped feeding or moved out of sight or was disturbed. A total of 427 feeding sequences were recorded: 133 grey plover, 145 Kentish plover and 149 ringed plover. Data were extracted from the tapes using a multi-event recorder computer program and peck rates and movement periods (per min) determined. The movement period, proportional to plover pacing rate, is a gross measure of the searching effort [30, 37].

For each time period and for each sub-area, gull densities, total bird densities and air temperatures were recorded.

All data were collected using $10 \times 50$ binoculars and a 30-90 × 60 telescope.

\subsection{Macroalgal and macrobenthic biomass}

Quantitative samples were taken fortnightly in the three sub-areas, from October 1993 to May 1994, for macrobenthos, and with a fortnightly periodicity from October to December 1993 and weekly from January to May 1994 for macroalgae. Ten replicates were randomly sampled in each sub-area by manual corer [1] (141 $\mathrm{cm}^{2}$ area, approximately $3 \mathrm{~L}$ volume). All the biological samples were sieved in situ over a $0.5-\mathrm{mm}$ mesh, and then fixed in $4 \%$ neutralised formalin. In the laboratory, the organisms were separated, preserved in $70 \%$ ethanol, and identified. The invertebrates and macroalgae were dried for $48 \mathrm{~h}$ at $60{ }^{\circ} \mathrm{C}$ and weighed, then ignited in a muffle furnace for $8 \mathrm{~h}$ at $450{ }^{\circ} \mathrm{C}$ to obtain ash free dry weights (AFDW).

\subsection{Waders faeces analysis}

In 1995, during both the winter and summer, waders feeding at various points were watched to make sure that they had been feeding in the study area for at least $1 \mathrm{~h}$. The footprints of each species were distinguished and followed, and any droppings collected and frozen. Droppings contained very little identifiable material so they were collected in batches of five.

Dropping samples were washed with water through a $0.05-\mathrm{mm}$ mesh and examined in the laboratory, using a low powered $(6-45 \times)$ binocular microscope. The identifiable material was removed and measured.

Two methods were used to express the representativeness of the prey groups in the study wader diets. First, the average total number of each prey type items per dropping is expressed as a percentage of the average total number of prey fragments per dropping. Second, the occurrence of each prey in a dropping is counted and expressed as a percentage of the total number of droppings. An index of the frequency of utilisation is obtained [27].

\subsection{Statistical analysis}

Stepwise multiple-regression analysis [53] was used to test for any association between dependent and environmental variables. The dependent variables were: wader occurrence, peck rates and movement periods. A step-down procedure was used so that the effect of each variable in the presence of all others could be examined first, with the least significant variable being removed at every step. The analysis stopped when all the surviving variables had a significance level $<0.05$ [53]. Tests for normality (Kolmogorov-Smirnov test) and for homogeneity of variances (Cochran's C and Bartlett's tests) were performed for the dependent variables before carrying out the multiple-regression analysis [53]. Specific proportions of occurrence were arcsine transformed.

Analysis of variance (ANOVA) followed by Tukey's multiple comparison tests was used to estimate differences in the occurrence between the three sub-areas. The objective of this procedure was to evaluate the importance of the empirical and nominal classification of the sediments and seagrass meadows, attributed to the three sub-areas, on the specific patterns of use by the waders. The same procedure was used to compare the macroalgal biomasses of the three sub-areas.

The non-parametric Spearman rank correlation was used to explore inter-relationships between prey abundance (biomass and densities) and macroalgal biomass. 
Table I. Occurrence frequency (Fr) of prey in droppings (\%) and their mean percentage (Pe) per dropping (\%) of ringed plover, Kentish plover, grey plover and dunlin from the Mondego estuary.

\begin{tabular}{|c|c|c|c|c|c|c|c|c|}
\hline & \multicolumn{2}{|c|}{$\begin{array}{c}\text { Ringed plover } \\
\quad n=50\end{array}$} & \multicolumn{2}{|c|}{$\begin{array}{c}\text { Kentish plover } \\
n=135\end{array}$} & \multicolumn{2}{|c|}{$\begin{array}{c}\text { Grey plover } \\
n=200\end{array}$} & \multicolumn{2}{|c|}{$\begin{array}{c}\text { Dunlin } \\
n=170\end{array}$} \\
\hline & Fr $\quad(\%)$ & $\mathrm{Pe} \quad(\%)$ & Fr $\quad(\%)$ & $\mathrm{Pe} \quad(\%)$ & Fr $\quad(\%)$ & $\mathrm{Pe} \quad(\%)$ & Fr $\quad(\%)$ & $\mathrm{Pe} \quad(\%)$ \\
\hline \multicolumn{9}{|l|}{ Polychaeta } \\
\hline Nereis diversicolor & 66.67 & 31.58 & 37.04 & 10.64 & 60.00 & 16.33 & 35.20 & 18.71 \\
\hline Other & 33.33 & 10.53 & 11.10 & 2.41 & 22.50 & 8.80 & 29.41 & 7.48 \\
\hline \multicolumn{9}{|l|}{ Gastropoda } \\
\hline Hydrobia ulvae & 33.33 & 26.32 & 74.07 & 59.04 & 47.50 & 24.55 & 50.00 & 31.97 \\
\hline \multicolumn{9}{|l|}{ Bivalvia } \\
\hline Cerastoderma edule & 33.33 & 10.53 & 37.04 & 9.64 & - & - & 2.94 & 0.38 \\
\hline Scrobicularia plana & 16.67 & 5.26 & 22.22 & 6.02 & 30.00 & 9.89 & 2.94 & 1.20 \\
\hline Amphipoda & 33.33 & 15.79 & 11.11 & 4.22 & 27.50 & 34.14 & 44.12 & 33.74 \\
\hline \multicolumn{9}{|l|}{ Decapoda } \\
\hline Carcinus maenas & - & - & 18.5 & 6.83 & 15.00 & 5.67 & 17.65 & 6.15 \\
\hline Diptera & - & - & 7.41 & 1.20 & 2.50 & 0.63 & 2.94 & 0.38 \\
\hline
\end{tabular}

\section{RESULTS}

\subsection{Effects of environmental factors on distribution patterns and feeding behaviour of waders}

A total of 62 macrobenthic species was identified. Table I shows the eight main prey groups selected by waders, and their representativeness in the diet. With respect to the average total number of each prey type items per dropping $(\%)$, the amphipods constituted the principal prey for grey plover (34.14\%) and for dunlin $(33.74 \%)$. Hydrobia ulvae was the principal prey for Kentish plover $(59.04 \%)$ and also an important prey for the other species, ringed plover $(26.32 \%)$, grey plover $(24.55 \%)$ and dunlin $(31.97 \%)$. The principal prey for ringed plover was Nereis diversicolor $(31.58 \%)$.

A total of three dependent and twelve independent variables were considered in the multiple-regression analysis to test any possible correlation between the occurrence and feeding behaviour of waders and the environmental variables: macroalgal biomass, gull densities, total bird densities (excluding the species in focus), air temperature and prey biomass (table II).

\subsubsection{Dunlin (Calidris alpina)}

Dunlin distribution seemed to be negatively affected by gull densities and macroalgal biomass. Clearly, dunlin were deterred from places where gulls were more abundant and/or the macroalgal biomass was higher, causing a decrease in the occurrence of this wader (figure 2). With regard to positive associations, the total bird densities and one of the main prey of dunlin, Nereis diversicolor (see table I), contributed significantly to the presence of feeding dunlin in the study areas (figure 2).

Table II. Specification of all variables considered for this study.

\begin{tabular}{|c|c|}
\hline Variables & Specification \\
\hline \multicolumn{2}{|l|}{ Wader variables } \\
\hline \multicolumn{2}{|c|}{ Specific proportion of occurrence $(\mathrm{P})$ See text } \\
\hline Peck rates $(\mathrm{PEK})$ & Pecks per minute \\
\hline Movement periods (MOV) & Seconds per minute \\
\hline \multicolumn{2}{|l|}{ Independent variables } \\
\hline Macroalgal biomass (ALG) & $\mathrm{g} \cdot \mathrm{m}^{-2}(\mathrm{AFDW})(4$ species $)$ \\
\hline Gull densities (GUL) & Birds $\cdot h^{-1}$ (3 species) \\
\hline Total bird densities (TOT) & $\begin{array}{l}\text { Birds } \cdot \mathrm{ha}^{-1} \text { (waders, gulls, } \\
\text { herons, terns) }\end{array}$ \\
\hline Air temperature (AIR) & ${ }^{\circ} \mathrm{C}$ \\
\hline Nereis diversicolor (NER) & $\mathrm{g} \cdot \mathrm{m}^{-2}(\mathrm{AFDW})$ \\
\hline Other Polychaeta (POL) & $\mathrm{g} \cdot \mathrm{m}^{-2}$ (AFDW) (31 species) \\
\hline Hydrobia ulvae (ULV) & $\mathrm{g} \cdot \mathrm{m}^{-2}(\mathrm{AFDW})$ \\
\hline Cerastoderma edule (EDU) & $\mathrm{g} \cdot \mathrm{m}^{-2}(\mathrm{AFDW})$ \\
\hline Scrobicularia plana (PLA) & $\mathrm{g} \cdot \mathrm{m}^{-2}(\mathrm{AFDW})$ \\
\hline Amphipoda (AMP) & $\mathrm{g} \cdot \mathrm{m}^{-2}(\mathrm{AFDW})(5$ species $)$ \\
\hline Carcinus maenas (CAR) & $\mathrm{g} \cdot \mathrm{m}^{-2}(\mathrm{AFDW})$ \\
\hline Diptera larvae (DIP) & $\mathrm{g} \cdot \mathrm{m}^{-2}(\mathrm{AFDW})(3$ species $)$ \\
\hline
\end{tabular}




\section{Proportion of Occurrence}

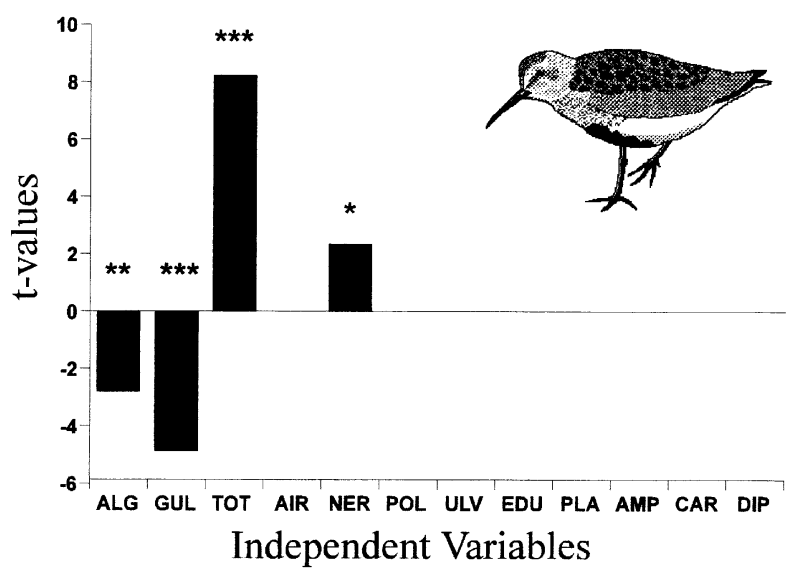

Figure 2. The correlates, selected by automatic stepwise regression analysis, of the variation in dunlin occurrence. The codes found in table II of the variables selected, t-values and significance levels (* $P<0.05$; ** $P<0.01$; *** $P<0.001)$ are shown. For variables not selected, the t-values are not shown.

\subsubsection{Kentish plover (Charadrius alexandrinus)}

With regard to distribution, gull density and Hydrobia ulvae biomass were negatively associated with Kentish plover presence. As for dunlin, the presence of high gull densities seemed to decrease Kentish plover occurrence (figure $3 a$ ). The negative association with $H$. ulvae was unexpected since it involved a very important prey for this plover (table I, figure $3 a$ ). The positive association between Kentish Plover presence in feeding areas and total bird densities were also statistically significant (figure $3 a$ ).

With regard to feeding behaviour, peck rates of Kentish plover were negatively associated with Nereis diversicolor biomass and positively with Scrobicularia plana, Diptera larvae and macroalgal biomass (figure $3 b$ ). Unexpected were the decrease in Kentish plover peck rate with the increase of the relatively important prey $N$. diversicolor, and the increase with the macroalgal growth (figure $3 b$ ). With regard to searching effort, the increase of the important prey $H$. ulvae was associated with low movement periods (figure $3 c$ ). Air temperature was negatively associated with Kentish plover movement periods (figure 3c).

\section{Proportion of Occurrence}

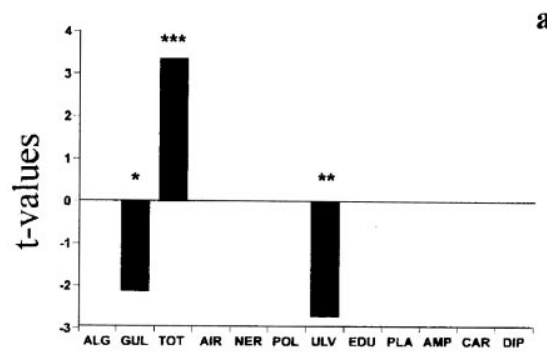

Peck Rate

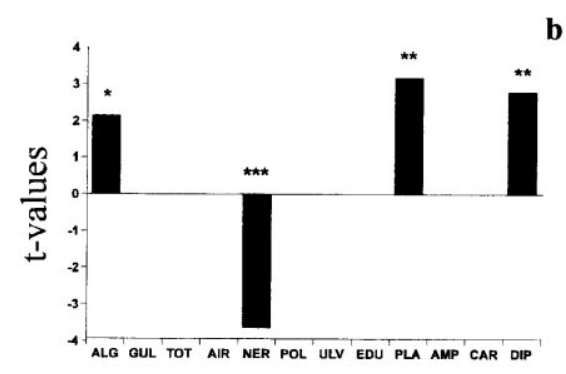

a

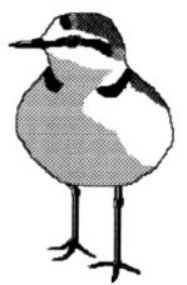

Movement Periods

b

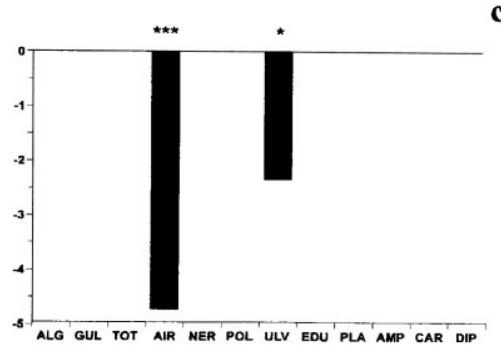

Figure 3. The correlates, selected by automatic stepwise regression analysis, of the variation in proportion of occurrence (a), peck rates (b) and movement periods (c) of Kentish plover. The codes found in table II of the variables selected, t-values and significance levels (* $P<0.05$; ** $P<0.01$;

c** $P<0.001)$ are shown. For variables not selected, the t-values are not shown.

Independent Variables 


\section{Proportion of Occurrence}

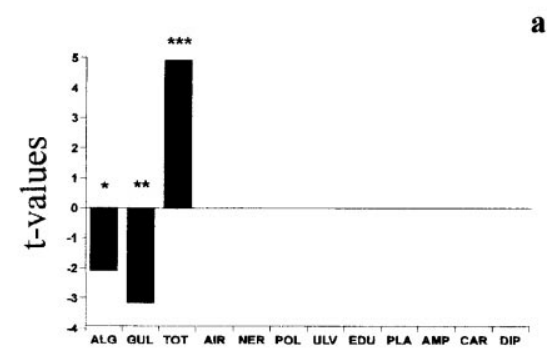

Peck Rate

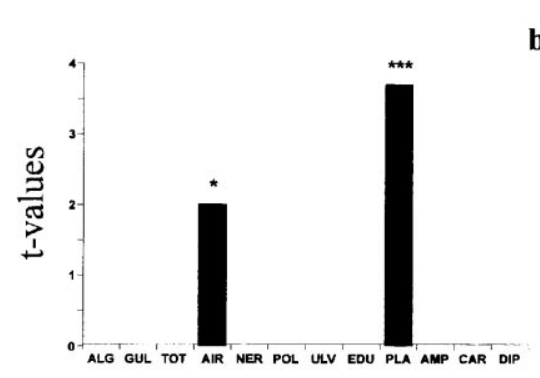

a

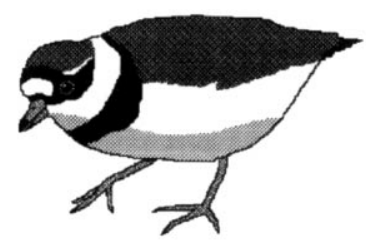

Movement Periods

b

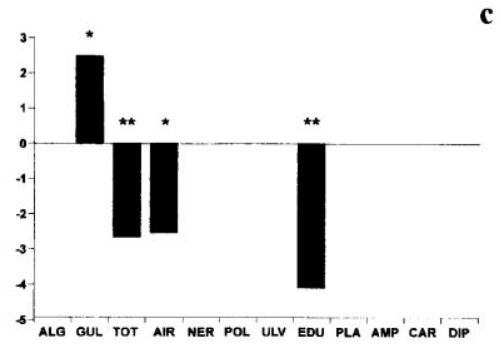

Figure 4. The correlates, selected by automatic stepwise regression analysis, of the variation in proportion of occurrence (a), peck rates (b) and movement periods (c) of ringed plover. The codes found in table II of the variables selected, t-values and significance levels

c $\quad(* P<0.05 ; * * P<0.01 ; * * * P<0.001)$ are shown. For variables not selected, the t-values are not shown.

Independent Variables

\subsubsection{Ringed plover (Charadrius hiaticula)}

As for the preceding species, total bird density had a positive influence on ringed plover occurrence (figure $4 a$ ). The negative associations were concerned with the effects of gull densities and macroalgal biomass (figure 4a).

With regards to feeding behaviour, only gull density seemed to contribute to increase ringed plover searching effort (figure 4c). In all other significant associations, the independent variable increase had an apparent positive impact on ringed plover feeding behaviour. High total bird densities were associated with a decrease in the movement periods (figure 4c). Increase in air temperature was associated with an increase in peck rate and a decrease of movement periods (figure $4 b, c$ ). Regarding ringed plover prey, only bivalves biomass had an apparent positive effect on feeding behaviour. The increase of Scrobicularia plana was associated with high peck rates (figure $4 b$ ) and the increase of Cerastoderma edule was associated with low movement periods (figure 4c).

\subsubsection{Grey plover (Pluvialis squatarola)}

Macroalgal biomass was responsible for the decrease in grey plover occurrence (figure $5 a$ ). In com- mon with the general trend seen for other waders, increases in grey plover occurrence were related to total bird densities (figure $5 a$ ). The increase in the Diptera larvae group biomass corresponded to high grey plover abundance (figure $5 a$ ). The other prey influences on grey plover distribution were negative and associated with the increase in Carcinus maenas and polychaete group biomass (figure $5 a$ ).

With regard to feeding behaviour, air temperatures and polychaetes were negatively associated with grey plover peck rate (figure $5 b$ ). Diptera larvae group and Scrobicularia plana biomass appeared to have a positive influence on grey plover peck rate (figure $5 b$ ). Relative to grey plover movement period, air temperatures and two of the main prey groups were associated with low grey plover movement periods (figure 5c).

The regression equations, and their significance, for all the combinations reported are shown in table III.

\subsection{Prey abundance in relation to macroalgal biomass}

Contrary to investigations from around the world [5, $9,15,17,28,43,44,48]$, there was no evidence that tidal flats covered by green algal mats are pernicious to 


\section{Proportion of Occurrence}

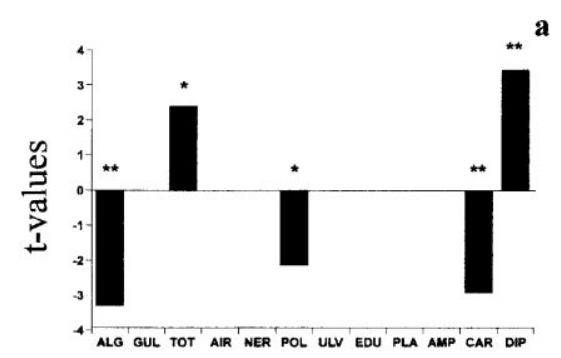

Peck Rate

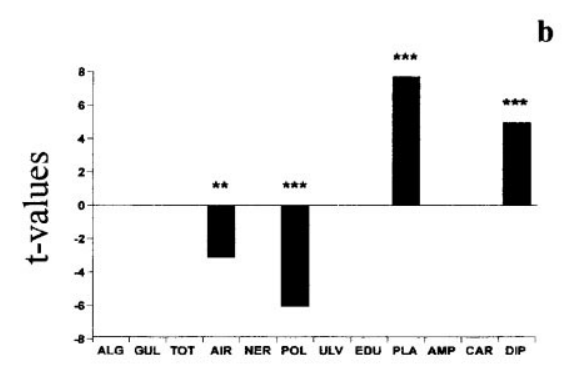

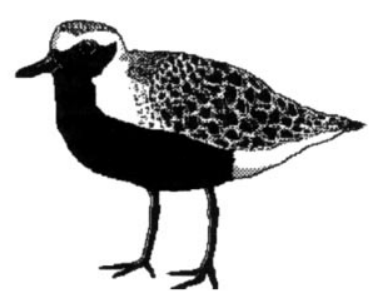

Movement Periods

b

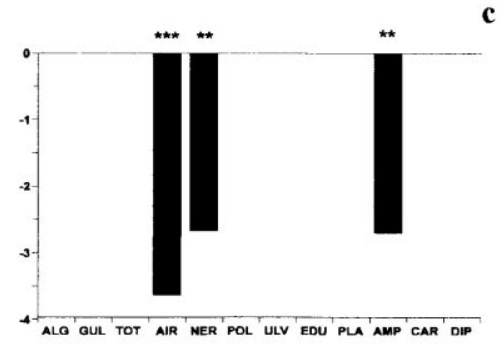

Figure 5. The correlates, selected by automatic stepwise regression analysis, of the variation in proportion of occurrence (a), peck rates (b) and movement periods (c) of grey plover. The codes found in table II of the variables selected, t-values and significance levels $\quad * P<0.05 ; \quad * * P<0.01$; *** $P<0.001)$ are shown. For variables not selected, the t-values are not shown.

\section{Independent Variables}

the most important macroinvertebrate groups [22, 25]. In our sampling plots or sub-areas, the reverse was in fact the case. Apart from some statistically non- significant associations, all the significant associations between prey densities or biomass and macroalgal biomass were positive. The Spearman rank correlation

Table III. The regression equations, the coefficient of determination $\left(R^{2}\right)$ and F-values and their significance level $(* * P<0.01$; $* * * P<0.001)$ for all combinations reported, as selected by stepwise multiple regression. The specification of all variable codes is expressed in table II.

\begin{tabular}{|c|c|c|c|}
\hline Equations & $\mathrm{DF}$ & $R^{2}$ & $\mathrm{~F}$ \\
\hline \multicolumn{4}{|l|}{ Calidris alpina } \\
\hline $\mathrm{P}=0.192-0.006(\mathrm{GUL})+0.004(\mathrm{TOT})-0.010(\mathrm{ALG})+0.102(\mathrm{NER})$ & 47 & 0.64 & $19.51 * * *$ \\
\hline \multicolumn{4}{|l|}{ Charadrius alexandrinus } \\
\hline $\mathrm{P}=0.373-0.003(\mathrm{GUL})+0.002(\mathrm{TOT})-0.006(\mathrm{ULV})$ & 47 & 0.40 & $9.88 * * *$ \\
\hline $\mathrm{PEK}=12.232+0.089(\mathrm{ALG})-3.002(\mathrm{NER})+0.521(\mathrm{PLA})+171.655(\mathrm{DIP})$ & 143 & 0.11 & $4.47 * *$ \\
\hline $\mathrm{MOV}=32.257-0.98(\mathrm{AIR})-0.117(\mathrm{ULV})$ & 143 & 0.16 & $13.56^{* * *}$ \\
\hline \multicolumn{4}{|l|}{ Charadrius hiaticula } \\
\hline $\mathrm{P}=0.3-0.005(\mathrm{GUL})+0.003(\mathrm{TOT})-0.005(\mathrm{ALG})$ & 47 & 0.40 & $9.90 * * *$ \\
\hline $\mathrm{PEK}=5.015+0.28(\mathrm{AIR})+0.342(\mathrm{PLA})$ & 148 & 0.11 & $8.62 * * *$ \\
\hline $\mathrm{MOV}=37.635-0.022(\mathrm{TOT})+0.186(\mathrm{GUL})-0.743(\mathrm{AIR})-1.688(\mathrm{EDU})$ & 148 & 0.15 & $6.56 * * *$ \\
\hline \multicolumn{4}{|l|}{ Pluvialis squatarola } \\
\hline $\mathrm{P}=0.339+0.001(\mathrm{TOT})-0.008(\mathrm{ALG})-0.305(\mathrm{POL})-0.49(\mathrm{CAR})+6.698(\mathrm{DIP})$ & 47 & 0.37 & $4.89 * *$ \\
\hline $\mathrm{PEK}=9.973-0.343(\mathrm{AIR})-12.62(\mathrm{POL})+0.574(\mathrm{PLA})+95.372(\mathrm{DIP})$ & 132 & 0.40 & $21.07 * * *$ \\
\hline $\mathrm{MOV}=42.261-1.084(\mathrm{AIR})-4.51(\mathrm{NER})-23.213(\mathrm{AMP})$ & 132 & 0.12 & $6.02 * * *$ \\
\hline
\end{tabular}


Table IV. Values of the Spearman correlation coefficient (rs) and their significance level (** $P<0.01$; *** $P<0.001)$ with macroalgal biomass against macroinvertebrate density and biomass $(n=48)$.

\begin{tabular}{lc}
\hline Macroinvertebrates & Macroalgae biomass $\left(\mathrm{g} \cdot \mathrm{m}^{-2}\right)$ \\
\hline Density $\left(\right.$ ind $\left.\cdot \mathrm{m}^{-2}\right)$ & 0.2716 \\
Nereis diversicolor & -0.0655 \\
Polychaeta group & 0.1907 \\
Hydrobia ulvae & $0.4043^{* *}$ \\
Cerastoderma edule & 0.1546 \\
Scrobicularia plana & $0.3938^{* *}$ \\
Amphipoda group & $0.5044^{* * *}$ \\
Carcinus maenas & $0.4994^{* * *}$ \\
Diptera group & $\mathrm{rs}$ \\
Biomass (g·m ${ }^{-2}$ ) & 0.1682 \\
Nereis diversicolor & 0.2296 \\
Polychaeta group & 0.2427 \\
Hydrobia ulvae & $0.4551^{* *}$ \\
Cerastoderma edule & 0.1004 \\
Scrobicularia plana & $0.4133^{* *}$ \\
Amphipoda group & $0.4251^{* *}$ \\
Carcinus maenas & $0.4471^{* *}$ \\
Diptera group &
\end{tabular}

coefficients, and their significance, for the prey groups correlates of variations in macroalgal biomass, are shown in table $I V$.

\subsection{Influence of sub-area sediment characteristics and epistructures}

In order to test the hypothesis that foraging birds were not indifferent to tidal flats distinguished by different sediment characteristics or by the presence or absence of epistructures such as green algal mats and seagrass meadows, a one-way ANOVA was conducted for two situations: (i) for wader preference between the three distinct sub-areas with respect to sediment characteristics and to seagrass presence; and (ii) for macroalgal growth differences between these subareas.

Only Kentish plover clearly preferred sub-area 3 $(\mathrm{F} 2,45=8.177, P<0.001)$ which corresponded to muddy-sand substrates without Zostera noltii meadows. Considering the muddy substrates covered by vegetation, Kentish plover preferred sub-area 2, corresponding to sparse $Z$. noltii meadows. Nevertheless, the statistically significant trend for preferred sub-area 3 , was not supported by the Tukey's test for dunlin $(\mathrm{F} 2,45=3.959, \quad P<0.05)$ and ringed plover $(\mathrm{F} 2,45=3.662, P<0.05)$. There was no statistically significant sub-area preference by grey plover $(\mathrm{F} 2,45=0.079, \mathrm{~ns})$.
Macroalgal biomass was less intense in sub-area 3, but this was not confirmed by Tukey's test $(\mathrm{F} 2,45=3.340, P<0.05)$.

\section{DISCUSSION}

This study shows that foraging waders are not indifferent to the effects of environmental factors, sediment characteristics and epistructures when selecting feeding microhabitats. The results confirmed that waders did indeed respond directly or indirectly in their distribution patterns to these factors.

\subsection{Macroalgal blooms}

In agreement with some previous studies that investigated the biological consequences of macroalgal blooms on estuarine upper trophic level organisms in general $[8,9,28]$ and on waders in particular $[5,29$, $41,42]$, we found that tidal flats covered by macroalgal mats were unattractive to feeding waders. In fact, when macroalgal growth had a significant effect on use of intertidal sub-areas by waders, it was always negative for most of the species studied. In an earlier study on the possible effects of macroalgal blooms on birds in the Mondego estuary, Múrias et al. [32] suggested that the presence of macroalgae on the sediment does not strongly influence the feeding distribution of the waders. These apparent conflicting results are explained by the different spatial scales of the two studies and in the level of control of potentially influential variables. At the large scale (for the total intertidal area and with gross information on the biomass of macroalgal mats), the capacity to discern and detect effects was naturally limited. The present study clarified, at a local scale, that several factors were important.

Contrary to the effects on distribution, macroalgal blooms do not influence negatively the feeding behaviour parameters of the three plovers. For Kentish plover, the reverse was the case, increasing their peck rate when macroalgal blooms occurred. Nevertheless, Kentish plover clearly preferred sub-area 3 which seemed less affected by macroalgal blooms. Consequently, most of the behavioural records for this plover were made in sub-area 3 where tidal flat sediments were only covered by a very sparse thick layer of macroalgae. Everett [9] reported that the anoxia observed beneath such mats could lead either to killing invertebrates or forcing them to escape by moving to the algal-free sediment surface. On the other hand, some species are able to develop new opportunistic communities associated with high algal biomass [9]. Our results suggest that macroinvertebrates that are normally associated with algal mats such as amphi- 
pods [45] and Carcinus maenas [18] proliferated when macroalgal biomass was high (table IV). These species then become more visible to the plovers, contributing to the observed increased Kentish plover peck rates. For grey and ringed plover, birds seemed not to be significantly influenced in their feeding behaviour during the macroalgal season.

\subsection{Other influential factors}

\subsubsection{Prey abundance}

Several studies have shown, at local or regional levels, that the distribution of waders within and between estuaries is determined by the distribution and abundance of their prey [13, 20, 39]. The optimal foraging theory predicts that predators should aggregate in areas where their net rate of energy gain is maximal [46]. The quality of different feeding habitats can be directly measured in studies on food selection, intake rates and distribution patterns of waders explained accordingly [11]. The present study indicates that close positive relationships exist between the distribution and peck rate (the converse for the searching effort) of some study waders and prey abundance (biomass). However, there are several apparent deviations from these theoretical predictions and more careful examination avoiding linear interpretations and considering the possible masked effect of other factors, such as physical habitat properties $[20,51]$, would be useful.

\subsubsection{Gull density}

The three gull species that occurred in the study, black-headed gull (Larus ridibundus), lesser blackbacked gull (L. fuscus), and yellowlegs gull (L. cachinnans) are kleptoparasitic on waders (Cabral, unpubl. data). On rare occasions, waders also stole from each other (both within and between species). Kallander [19] and Thompson and Barnard [49] reported that black-headed gulls can obtain food in excess of their daily energy requirement solely by stealing prey from plovers. When gulls were present at the study sites, kleptoparasitism might represent a real perturbation to wader distribution and feeding behaviour. Our results suggested that increased gull densities had a persistent negative impact on most wader distributions and on the feeding behaviour of one of the three plovers by increasing searching effort. Only grey plover did not appear to be significantly affected by the presence of gulls. The low numbers of this species might have reduced the probability of interactions with gulls.

\subsubsection{Total bird density}

The total bird density in the sub-areas was recorded to measure and examine the importance of interference on feeding. Interference is defined as the immediate and reversible reduction in intake rate associated with increased bird density [11]. The mechanisms of interference proposed by Goss-Custard $[11,12]$ is that at high bird densities, prey are less available because, in response to superficial vibration, they retreat down their burrows, or the small vulnerable fraction is depleted, or individual birds are unable to pursue the optimum search path encouraging flocking birds to spread out. Contrary to this thesis, we did not find that the total bird density increase negatively affected feeding. In fact, the reverse was the case. At high bird densities, waders tended to flock and some of them increased their feeding efficiency (decreasing searching effort). One possible explanation for this is that the maximum numbers recorded in sub-areas were not sufficiently high to cause interference.

\subsubsection{Air temperature}

Air temperature, which is highly correlated with mud temperature [3], was recorded because it might affect prey behaviour, with repercussions on predator behaviour and distribution. Many intertidal invertebrates reduce their level of activity and tend to move deeper into the sediment when the temperature falls [3, $7,10,12,35,39,50,54]$. As a result, most of the important prey are less active and less available at low temperatures. With the exception of grey plover peck rate, lower air temperatures were associated with a tendency for plovers to decrease peck rates and/or increase searching effort. Nevertheless, the expectation that temperature would be a reliable predictor of feeding behaviour and distribution patterns was only weakly supported here since grey plover peck rate had the reverse tendency and no significant effect was found on wader distributions.

\subsubsection{Sediment characteristics and epistructures}

Sediment characteristics can be crucial in microhabitat selection by waders since prey abundance depends largely on the particle size composition of the substratum [24]. It is possible that wader densities responded directly to sediment characteristics rather than to the abundance of their prey per se [51]. In the analysis of variance, the effect of sub-area attributes, namely sediment structure and seagrass presence, on microhabitat selection was significant for most waders. With the exception of grey plover, waders seemed to 
prefer sub-area 3 characterised by muddy-sand substrates without seagrass. Moreira [31] reported the same preference for Kentish plover and similar preferences for ringed plover and dunlin in the Tagus estuary (Portugal). However, sub-area 3 was also less affected by macroalgal blooms and it is difficult to separate the effects of these two factors.

Overall, the results suggest predominant and consistent negative effects of gull densities and macroalgal biomass on waders. The macroalgal blooms persist for several months and hence have a different magnitude of effect when compared with sporadic and aleatory factors such as the presence of gulls. However, we were unable to prove that the presence of macroalgae on the sediment is detrimental to wader prey, perhaps because the total amount of the area of the estuary covered by weed during the study period never exceeded $36 \%$ [32], and the affected areas were surrounded by important algal-free adjacent areas that ensured renewable prey recruitment. Nevertheless, an increase in biomass of macroalgae due to the progressive eutrophication of the Mondego estuary, may eliminate the seagrass meadows, and consequently, the loss of invertebrate species dependent on this habitat with a general reduction in prey species diversity, and the consequent alteration of food webs [28]. In a long-term perspective, an increase of dense and contiguous macroalgal mats, covering large areas of the intertidal flats, may affect directly or indirectly all wader species in the Mondego estuary.

\section{Acknowledgments}

This paper was supported by the Programme Mast II (MAS 2 CT 92 0036) and by the JNICT (Portuguese National Board of Scientific Research) through grants BM/3261/92-IG (J.A. Cabral), BM/1340/91-IG (M.A. Pardal) and BD/331/92 (T. Múrias). The authors are indebted to all the colleagues from the University of Coimbra who assisted in field and laboratory work.

\section{REFERENCES}

[1] Abrantes A., Pinto F., Moreira M.H., Ecology of the polychaete Nereis diversicolor in the Canal de Mira (Ria de Aveiro, Portugal): Population dynamics, production and oogenic cycle, Acta Oecol. 20 (1999) 267-283.

[2] Azeiteiro U.M.M., Marques J.C., Temporal and spatial structure in the suprabenthic community of a shallow estuary (western Portugal: Mondego river estuary), Acta Oecol. 20 (1999) 333-342.

[3] Baker M.C., Foraging behaviour of black-bellied plovers (Pluvialis squatarola), Ecology 55 (1974) 162-167.

[4] Baker M.C., Baker A.E.M., Niche relationships among six species of shorebirds on their wintering and breeding ranges, Ecol. Monogr. 43 (1973) 193-212.
[5] Desprez M., Rybarczyk H., Wilson J.G., Ducrotoy J.P., Sueur F., Olivesi R., Elkaim B., Biological impact of eutrophication in the Bay of Somme and the induction and impact of anoxia, Neth. J. Sea Res. 30 (1992) 149-159.

[6] Dijk G.M., Liere L., Admiraal W., Bannink B.A., Cappon J.J., Present state of the water quality of European rivers and implications for management, Sci Total Environ. 145 (1994) 187-195.

[7] Evans P.R., Adaptations shown by foraging shorebirds to cyclical variations of their intertidal invertebrate prey, in: Naylor E., Hartnoll R.G. (Eds.), Cyclic Phenomena in Marine Plants and Animals, Pergamon Press, Oxford, 1978, pp. 357-366.

[8] Everett R.A., Intertidal distribution of infauna in a central California lagoon: the role of seasonal blooms of macroalgae, J. Exp. Mar. Biol. Ecol. 150 (1991) 223-247.

[9] Everett R.A., Macroalgae in marine soft-sediment communities: effects on benthic faunal assemblages, J. Exp. Mar. Biol. Ecol. 175 (1994) 253-274.

[10] Goldstein D.L., Estimates of daily energy expenditure in birds: The time-energy budget as an integrator of laboratory and field studies, Am. Zool. 28 (1988) 829-844.

[11] Goss-Custard J.D., Feeding dispersion in some overwintering wading birds, in: Crook J.H. (Ed.), Social Behaviour of Birds and Mammals, Academic Press, London \& New York, 1970, pp. 3-35.

[12] Goss-Custard J.D., Foraging behaviour of wading birds and the carrying capacity of estuaries, in: Sibly R.M., Smith R.H. (Eds.), Behavioural Ecological. Ecological Consequences of Adaptative Behaviour, Blackwell Scientific Publications, Oxford, 1985, pp. 169-188.

[13] Goss-Custard J.D., Jones R.E., Newbery P.E., The ecology of the wash. I. Distribution and diet of wading birds (Charadrii), J. Appl. Ecol. 14 (1977) 681-700.

[14] Grant J., A bioenergetic model of shorebird predation on infaunal amphipods, Oikos 37 (1981) 53-62.

[15] Hardy F.G., Evans S.M., Tremayne M.A., Long-term changes in the marine macroalgae of three polluted estuaries in north-east England, J. Exp. Mar. Biol. Ecol. 172 (1993) 81-92.

[16] Hickel W., Mangelsdorf P., Berg J., The human impact in the German Bight: Eutrophication during three decades (19621991), Helgol. Wiss. Meeresunters. 47 (1993) 243-263.

[17] Hodgkin E.P., Hamilton B.H., Fertilizers and eutrophication in southwestern Australia: Setting the scene, Fert. Res. 36 (1993) 95-103.

[18] Isaksson I., Phil L., Montfrans J., Eutrophication-related changes in macrovegetation and foraging of young cod (Gadus morhua L.): A mesocosm experiment, J. Exp. Mar. Biol. Ecol. 177 (1994) 203-217.

[19] Kallander H., Piracy by Black-Headed gulls on Lapwings, Bird Study 24 (1977) 186-194.

[20] Kalejta B., Hockey P.A.R., Distribution of shorebirds at the Berg River Estuary, South Africa, in relation to foraging mode, food supply and environmental features, Ibis 136 (1994) 233-239.

[21] Lillebø A.I., Flindt M.R., Pardal M.A., Marques J.C., The effect of macrofauna, meiofauna and microfauna on the degradation of Spartina maritima detritus from a salt marsh area, Acta Oecol. 20 (1999) 249-258. 
[22] Lillebø A.I., Pardal M.A., Marques J.C., Population structure, dynamics and production of Hydrobia ulvae (Pennant) (Mollusca: Prosobranchia) along an eutrophication gradient in the Mondego estuary (Portugal), Acta Oecol. 20 (1999) 289-304.

[23] Marques J.C., Maranhão P., Pardal M.A., Human impact assessment on the subtidal macrobenthic community structure in the Mondego estuary (Western Portugal), Estuar. Coast. Shelf Sci. 37 (1993) 403-419.

[24] Marques J.C., Rodrigues L.B., Nogueira A.J.A., Intertidal macrobenthic communities structure in the Mondego estuary (Western Portugal): reference situation, Vie Milieu 43 (1993) 177-187.

[25] Martins I., Oliveira J.M., Flindt M.R., Marques J.C., The effect of salinity on the growth rate of the macroalgae Enteromorpha intestinalis (Chlorophyta) in the Mondego estuary (west Portugal), Acta Oecol. 20 (1999) 259-265.

[26] Masero J.A., Pérez-González M., Basadre M., Otero-Saavedra M., Food supply for waders (Aves: Charadrii) in an estuarine area in the Bay of Cádiz (SW Iberian Peninsula), Acta Oecol. 20 (1999) 429-434.

[27] Mazé R.A., Domínguez J., Pérez-Cardenal D., Diet of $L i$ pophrys pholis (L.) (Teleostei, Blenniidae) in Cantabrian coastal waters (Spain), Acta Oecol. 20 (1999) 435-448.

[28] McComb A.J., Davis J.A., Eutrophic waters of southwestern Australia, Fert. Res. 36 (1993) 105-114.

[29] Metzmacher K., Reise K., Experimental effects of tidal flat epistructures on foraging birds in the Wadden Sea, Ophelia 6 (1994) 217-225.

[30] Michaud G., Ferron J., Étude comparative des techniques de guête alimentaire de quatre espéces d'oiseaux limicoles, Nat. Can. 113 (1986) 281-292.

[31] Moreira F., Patterns of use of intertidal estuarine areas by feeding bird assemblages: A study in the Tagus estuary (Portugal), Ardeola 40 (1993) 39-53.

[32] Múrias T., Cabral J.A., Marques J.C., Goss-Custard J.D., Short-term effects of intertidal macroalgal blooms on the macrohabitat selection and feeding behaviour of wading birds in the Mondego estuary (West Portugal), Estuar. Coast. Shelf Sci. 43 (1996) 677-688.

[33] Múrias T., Cabral J.A., Lopes R., Marques J.C., Low-water use of the Mondego estuary (West Portugal) by waders (Charadrii), Ardeola 44 (1997) 79-91.

[34] Pardal M.A., Marques J.C., Bellan G., Spatial distribution and seasonal variation of subtidal polychaete populations in the Mondego estuary (western Portugal), Cah. Biol. Mar. 34 (1993) 497-512.

[35] Pienkowski M.W., Differences in habitat requirements and distribution patterns of plovers and sandpipers as investigated by studies of feeding behaviour, Verh. Orn. Ges. Bayern 23 (1979) 105-124.

[36] Pienkowski M.W., Diet and energy intake of grey and ringed plovers, Pluvialis squatarola and Charadrius hiaticula, in the non-breeding season, J. Zool. Lond. 197 (1982) 511-549.

[37] Pienkowski M.W., Changes in the foraging pattern of plovers in relation to enviromental factors, Anim. Behav. 31 (1983) 244-264.
[38] Piersma T., Hoenstra R., Dekinga A., Koolhaas A., Wolf P., Battley P., Wiersma P., Scale and intensity of intertidal habitat use by Knots Calidris canutus in the Western Wadden sea in relation to food, friends and foes, Neth. J. Sea Res. 31 (1993) 331-357.

[39] Piersma T., Goeij P., Tulp I., An evaluation of intertidal feeding habitats from a shorebird perspective: towards relevant comparisons between temperate and tropical mudflats, Neth. J. Sea Res. 31 (1993) 503-512.

[40] Puttick G.M., Foraging behaviour and activity budgets of curlew sandpipers, Ardea 67 (1979) 111-122.

[41] Raffaelli D., Conservation of Scottish estuaries, Proc. R. Soc. Edinb. 100B (1992) 55-76.

[42] Raffaelli D.G., Hull S.C., Milne H., Long-term changes in nutrients, weed mats and shorebirds in an estuarine system, Cah. Biol. Mar. 30 (1989) 259-270.

[43] Raffaelli D., Limia J., Hull S., Pont S., Interactions between the amphipod Corophium volutator and macroalgal mats on estuarine mudflats, J. Mar. Biol. Assoc. UK 71 (1991) 899-908.

[44] Schories D., Reise K., Germination and anchorage of Enteromorpha spp. in sediments of the Wadden Sea, Helgol. Wiss. Meeresunters. 47 (1993) 275-285.

[45] Soulsby P.G., Lowthion D., Houston M., Effects of macroalgal mats on the ecology of intertidal mudflats, Mar. Pollut. Bull. 13 (1982) 162-166.

[46] Stephens D.W., Krebs J.R., Foraging Theory, Princeton University Press, New Jersey, 1986, 247 p.

[47] Székely T., Bamberger Z., Predation of waders (Charadrii) on prey populations: An exclosure experiment, J. Anim. Ecol. 61 (1992) 447-456.

[48] Tapp J.F., Shillabeer N., Ashman C.M., Continued observations of the benthic fauna of the industrialised Tees estuary, 1979-1990, J. Exp. Mar. Biol. Ecol. 172 (1993) 67-80.

[49] Thompson D.B.A., Barnard C.J., Prey selection by plovers: Optimal foraging in mixed-species groups, Anim. Behav. 32 (1984) 554-563.

[50] Wiersma P., Piersma T., Effects of microhabitat, flocking, climate and migratory goal on energy expenditure in the annual cycle of red Knots, Condor 96 (1994) 257-279.

[51] Yates M.G., Goss-Custard J.D., Mcgrorty S., Lakhani K.H., DitDurell S., Clarke R.T., Rispin W.E., Moy I., Yates T., Plant R.A., Frost A.J., Sediment characteristics, invertebrate densities on the inner banks of the Wash, J. Appl. Ecol. 30 (1993) 599-614.

[52] Yeates J.S., Soils and fertilizer use in Southwestern Australia, Fert. Res. 36 (1993) 123-125.

[53] Zar J.H., Biostatistical Analysis, 2nd ed., Prentice-Hall International Inc., Englewood Cliffs, New Jersey, 1984.

[54] Zwarts L., Wanink J.H., How the food supply harvestable by waders in the Wadden Sea depends on the variation in energy density body weight, biomass, burying depth and behaviour of tidal-flat invertebrates, Neth. J. Sea Res. 31 (1993) 441-476. 